\title{
PENURUNAN MASA PELAYANAN JALAN AKIBAT KENDARAAN DENGAN BEBAN BERLEBIH
}

\author{
I Dewa Made Alit Karyawan'), Hasyim ${ }^{1)}$, dan Khairul Faqihi' ${ }^{1)}$ \\ 1) Jurusan Teknik Sipil, Universitas Mataram, Mataram, Nusa Tenggara Barat \\ dewaalit@unram.ac.id
}

\begin{abstract}
Road damage is caused by several factors, namely: unstable subgrade, climate, poor drainage system, materials, and work processes that do not meet the requirements. Besides that, vehicle traffic loads have a greater effect. Normal traffic load can maintain life as design. Problems arise when many vehicles pass with loads that exceed the required load limit. This will reduce the service life. Therefore, strict supervision of the maximum load at the weighbridge requires special attention. Especially if the road is an arterial road that is dominated by freight vehicles. The effect of decreasing pavement service life due to overloading can be done by comparing the service life with normal load and overload. The research was conducted on a national road section, namely Jalan Raya Ahmad Yani, located in Narmada, West Lombok Regency. The analysis was carried out on secondary data, namely the number of vehicles entering the weighbridge and daily traffic on average in 2018 and 2019. The results of the analysis are the number of equivalent axle loads and the Vehicle Damage Factor (VDF) on each type of vehicle with normal loads or more using the Bina Marga Method. Furthermore, the design life reduction analysis is carried out based on the cumulative results of Equivalent Standard Axle Load (ESAL) under normal load and overload conditions. The results of the analysis show that the equivalent value or VDF of normal load vehicles is 385120.1870 and VDF overload is 643207.3800 so that the percentage increase in VDF value is $67.01 \%$ and there is a decrease in age of 3.1 years, with the planned age of 10 years.
\end{abstract}

Keywords: overload, service life, vehicle damage factor 


\begin{abstract}
ABSTRAK
Kerusakan jalan disebabkan oleh beberapa faktor yaitu: tanah dasar yang tidak stabil, iklim, sistem drainase yang buruk, material dan proses kerja yang tidak memenuhi persyaratan. Selain itu beban lalu lintas kendaraan memiliki pengaruh yang lebih besar. Beban lalu lintas normal dapat mempertahankan masa layan sesuai rencana. Masalah muncul ketika banyak kendaraan melintas dengan beban melebihi batas yang dipersyaratkan. Karenaberdampak pada pengurangan umur layanan. Karena itu, pengawasan yang ketat di jembatan timbang terhadap kendaraan dengan beban lebih, memerlukan perhatian khusus. Apalagi jika jalan tersebut merupakan jalan arteri yang didominasi oleh kendaraan angkutan barang. Pengaruh penurunan umur pelayanan perkerasan akibat beban lebih dapat dilakukan dengan membandingkan umur layan dengan beban normal dan beban lebih. Penelitian dilakukan pada ruas jalan nasional yaitu Jalan Raya Ahmad Yani yang terletak di Narmada, Kabupaten Lombok Barat. Analisis dilakukan terhadap data sekunder yaitu jumlah kendaraan yang memasuki jembatan timbang dan lalu lintas harian rata-rata tahun 2018 dan 2019. Hasil analisis berupa jumlah beban sumbu ekivalen dan efek kerusakan (Vehicle Damage Factor/ VDF) pada masing-masing jenis kendaraan dengan muatan normal atau lebih yang menggunakan Metode Bina Marga. Selanjutnya, analisis pengurangan umur layan dilakukan berdasarkan hasil kumulatif Equivalent Standard Axle Load (ESAL) pada kondisi beban normal dan beban berlebih. Hasil analisis menunjukkan bahwa angka ekivalen atau VDF kendaran muatan normal sebesar 385120.1870 dan VDF muatan berlebih sebesar 643207.3800 sehingga diperoleh persantase peningkatan nilai VDF sebesar $67.01 \%$ serta terjadi penurunan umur sebesar 3.1 tahun dari umur rencana 10 tahun.
\end{abstract}

Kata kunci: beban lebih, masa layanan, vehicle damage factor 


\section{PENDAHULUAN}

Sebagai bagian dari jaringan jalan arteri, kendaraan yang melintas pada Ruas Jalan Ahmad Yani, Kecamatan Narmada, didominasi oleh kendaraan berat. Kendaraan tersebut berfungsi sebagai pendistribusi barang dan jasa. Kerusakan jalan yang diakibatkan oleh lalu-lintas pada ruas jalan tersebut dapat dilihat secara kasat mata. Kerusakan kontruksi jalan pada ruas tersebut adalah akibat beban kendaraan. Kerusakan menjadi lebih cepat ketika beban yang diangkut melebihi dari batas sesuai ketentuan. Kerusakan yang terlihat berupa retak-retak dan berlubang. Sebagian dari kerasakan yang terjadi sudah mengalami perbaikan berupa penambalan (patching).

Beberapa hal yang menjadi penyebab utama kerusakan jalan adalah cuaca esktrem, mutu pelaksanaan, drainase, beban berlebih, dan cuaca (Pardosi, 2010; Handayasari \& Cahyani, 2016). Kendaraan truk yang overloading (dengan beban berlebih) merupakan faktor dominan penyebab menurunnya kualitas kemantapan jalan (Yun, 2019).

Beban berlebih dapat mengakibatkan masa pelayanan berkurang dari masa layanan rencana (umur rencana). Ini terjadi, karena menimbulkan faktor rusak (VDF) yang lebih tinggi. Sehingga hal ini menjadi alasan mengapa perlu dilakukan kontrol terhadap kendaraan yang mempunyai bebean lebih. Tujuan kajian dalam artikel ini adalah mengkaji penurunan masa pelayanan jalan akibat kendaraan dengan beban berlebih.

\section{KAJIAN PUSTAKA}

\subsection{Penelitian Terkait}

Kajian pada ruas jalan dengan muatan berlebih (overload) yang menyebabkan kerusakan dilakukan oleh Safitra, Sendow, \& Pandey (2019). Persentase kendaraan berlebih berdasarkan jenisnya adalah pickup sebesar $54.4 \%$, truk ringan sebesar $47.7 \%$, truk sedang sebesar $70.1 \%$, truk berat sebesar $33.6 \%$, truk trailer 1.2-2 sebesar $34.5 \%$, truk trailer 1.2-2.2 sebesar $24.5 \%$, dan truk gandeng sebesar $40.0 \%$. Sehingga persentase peningkatan VDF komulatif akibat muatan berlebih (overload) adalah sebesar 59.5\%. Akibat beban berlebih tersebut terjadi penuruanan umur pelayanan sebesar $28.1 \%$ atau sebesar 2.81 tahun. Apriyadi \& Fauziah (2018), mendapatkan hal yang sama, dimana muatan berlebih aktual dapat menurunkan umur layanan. Dalam studinya, akibat muatan berlebih aktual, ditemukan terjadi peningkatan nilai VDF kumulatif, berdasarkan metode Bina Marga (Anonim, 1987) sebesar $\quad 86.7 \%$. Sedangkan, berdasarkan metode NAASRA (Anonim, 
2004) sebesar $81.6 \%$, dan dengan metode AASHTO (Anonim, 1993) sebesar 95.8\%. Sehingga penurunan umur rencana berdasarkan metode Bina Marga (Anonim, 1987) sebesar 4.14 tahun. Berdasar metode NAASRA (Anonim, 2004) sebesar 3.95 tahun dan dengan metode AASHTO (Anonim, 1993) sebesar 4.45 tahun. Berdasarkan hasil tersebut, maka terjadi peningkatan kebutuhan tebal perkerasan dari kondisi normal, akibat muatan berlebih aktual, berdasarkan metode Bina Marga (Anonim, 1987) sebesar 9.9\%. Sedangkan berdasarkan metode NAASRA (Anonim, 2004) sebesar $9.4 \%$ dan dengan metode AASHTO (Anonim, 1993) sebesar 10.7\%. Dapat disimpulkan bahwa persentase muatan berlebih yang terjadi dapat menurunkan umur rencana dan meningkatkan kebutuhan tebal perkerasan.

Pada kondisi beban sumbu kendaraan yang lebih dari $17.9 \%$ terhadap beban gandar maksimum. Mengakibatkan penurunan penurunan umur pelayanan sebesar 8 tahun (Sentosa \& Roza, 2012).

\subsection{Klasifikasi Jalan Raya}

Tabel 1, menunjukkan klasifikasi jalan umum di Indonesia menurut kelas jalan berdasarkan Pasal 19 UU No. 22 Tahun 2009 (Anonim, 2009).
Tabel 1. Klasifikasi Jalan berdasarakan

Kelas Jalan

\begin{tabular}{cccccc}
\hline \multirow{3}{*}{$\begin{array}{c}\text { Kelas } \\
\text { Jalan }\end{array}$} & Fungsi Jalan & \multicolumn{3}{c}{$\begin{array}{c}\text { Dimensi Kendaraan } \\
\text { Maksimum }\end{array}$} & $\begin{array}{c}\text { Muatan } \\
\text { Sumbu }\end{array}$ \\
\cline { 3 - 4 } & & $\begin{array}{c}\text { Pan- } \\
\text { jang } \\
(\mathrm{m})\end{array}$ & $\begin{array}{c}\text { Le- } \\
\text { bar } \\
(\mathrm{m})\end{array}$ & $\begin{array}{c}\text { Ting } \\
\text { gi }\end{array}$ & $\begin{array}{c}\text { Terberat } \\
(\mathrm{m})\end{array}$ \\
\hline Khusus & Arteri & 18 & 2.5 & 4.2 & $>10$ \\
\multirow{2}{*}{ I } & Arteri & 18 & 2.5 & 4.2 & 10 \\
& Kolektor & 18 & 2.5 & 4.2 & 10 \\
& Arteri & 12 & 2.5 & 4.2 & 8 \\
II & Kolektor & 12 & 2.5 & 4.2 & 8 \\
& Lokal & 12 & 2.5 & 4.2 & 8 \\
& Lingkungan & 12 & 2.5 & 4.2 & 8 \\
& Arteri & 9 & 2.1 & 3.5 & 8 \\
III & Kolektor & 9 & 2.1 & 3.5 & 8 \\
& Lokal & 9 & 2.1 & 3.5 & 8 \\
& Lingkungan & 9 & 2.1 & 3.5 & 8 \\
\hline
\end{tabular}

Sumber: Anonim, 2009

\subsection{Perkerasan Lentur}

Perkerasan lentur (flexible pavement) adalah perkerasan fleksibel dengan bahan terdiri dari bahan ikat dan agregat. Perkerasan ini umumnya terdiri dari beberapa lapis. Lapisan perkerasan lentur (flexible pavement) terdiri dari 3 lapisan. Lapisan perkerasan lentur ditunjukkan pada Gambar 1 dengan susunan sebagai berikut (Sukirman, 2010):

1. Lapisan Permukaan

2. Lapis pondasi atas (Base course)

3. Lapis pondasi bawah (Sub base course)

4. Lapis tanah dasar (Subgrade)

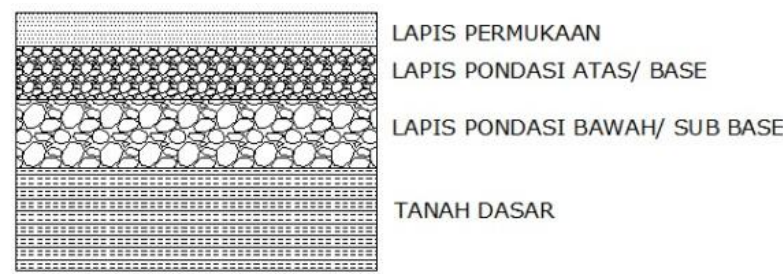

Gambar 1. Lapisan Perkerasan Lentur (Sumber: Sukirman, 2010) 


\subsection{Beban Sumbu Kendaraan}

Repetisi beban kendaraan dilimpahkan melalui roda kendaraan selama masa pelayanan jalan. Setiap kendaraan memiliki letak titik berat yang berbeda sesuai dengan jenisnya. Letak titik berat tersebut digunakan sebagai dasar untuk mendidstribusikan beban kendaraan ke masing-masing sumbunya. Karena itu, setiap jenis kendaraan mempunyai pola distribusi beban yang berbeda-beda. Distribusi beban sumbu dari berbagai jenis kendaraan, ditunjukkan pada Gambar 2.

\begin{tabular}{|c|c|c|c|c|}
\hline 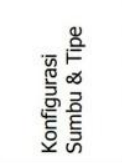 & 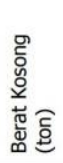 & 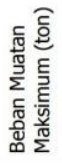 & 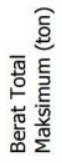 & \\
\hline $\begin{array}{c}1.1 \\
\text { Mobil } \\
\text { Penumpang }\end{array}$ & 1,5 & 0,5 & 2,0 & $\underset{50 \%}{D_{40 \%}}$ \\
\hline $\begin{array}{l}1.2 \\
\text { Bus }\end{array}$ & 3 & 6 & 9 & 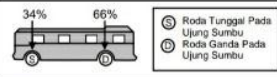 \\
\hline $\begin{array}{l}1.2 \mathrm{~L} \\
\text { Truk }\end{array}$ & 2,3 & 6 & 8,3 & 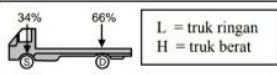 \\
\hline $\begin{array}{l}1.2 \mathrm{H} \\
\text { Truk }\end{array}$ & 4,2 & 14 & 18,2 & 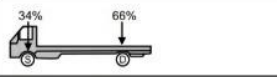 \\
\hline $\begin{array}{l}1.22 \\
\text { Truk }\end{array}$ & 5 & 20 & 25 & 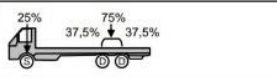 \\
\hline $\begin{array}{c}1.2+2.2 \\
\text { Trailer }\end{array}$ & 6,4 & 25 & 31,4 & 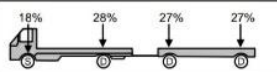 \\
\hline $\begin{array}{l}1.2+2 \\
\text { Trailer }\end{array}$ & 6,2 & 20 & 26,2 & 审 \\
\hline $\begin{array}{l}1.2+22 \\
\text { Trailer }\end{array}$ & 10 & 32 & 42 & 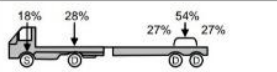 \\
\hline
\end{tabular}

Gambar 2. Distribusi Beban Sumbu dari Berbagai Jenis Kendaraan (Sumber: Sukirman, 2010)

\subsection{5 Angka Ekivalen Beban Sumbu}

Angka ekivalen (E) beban sumbu kendaraan adalah angka yang menyatakan perbandingan tingkat kerusakan yang ditimbulkan oleh suatu lintasan beban sumbu tunggal kendaraan terhadap tingkat kerusakan yang ditimbulkan oleh satu lintasan beban sumbu tunggal 8.16 ton 18000 lb (Abdillah, Paransa, Jansen, \& Manoppo, 2013). Sumbu tunggal 8.16 ton yang digunakan sebagai sumbu standar di Indonesia ditunjukkan pada Gambar 3.

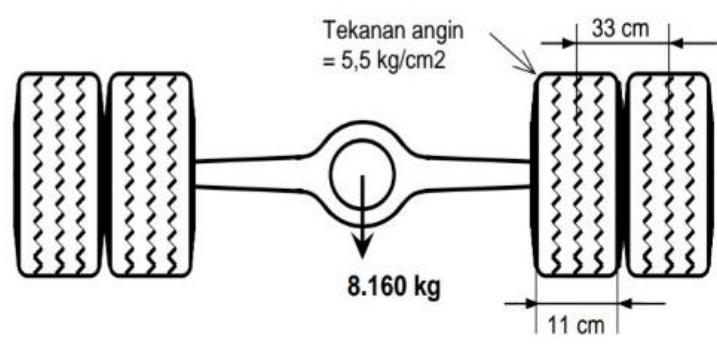

Gambar 2. Sumbu Standar 8.16 ton

Angka ekivalen masing-masing golongan beban sumbu untuk setiap sumbu kendaraan ditentukan dengan Persamaan 1 dan 2, sebagai berikut:

1. Angka ekivalen sumbu tunggal

$$
\mathrm{E}=1 \times\left[\frac{\mathrm{L}}{8160}\right]^{4}
$$

2. Angka ekivalen sumbu ganda

$$
\mathrm{E}=0,086 \times\left[\frac{\mathrm{L}}{8160}\right]^{4}
$$

dengan:

$$
\begin{aligned}
& \mathrm{E}=\text { Angka ekivalen sumbu } \\
& \mathrm{L}=\text { Beban sumbu }
\end{aligned}
$$

\subsection{Masa Pelayanan}

Umur pelayanan (umur rencana) adalah jumlah tahun dari saat jalan tersebut mulai dibuka untuk lalu lintas kendaraan, 
hingga diperlukan suatu perbaikan. Perbaikan tersebut dapat berupa perbaikan berat, atau pelapisan permukaan yang baru. Pemeliharaan perkerasan jalan harus tetap dilakukan selama umur rencana. Misalnya, penambahan lapisan non-structural yang berfungsi sebagai lapisan aus (Anonim, 2005).

Beban sumbu standar kumulatif atau Cumulative Equivalent Standart Axle Load (CESAL) selama umur rencana, dihitung menggunakan Persamaan 3 berikut (Anonim, 2005):

$$
\begin{aligned}
& \mathrm{W}_{18}=\sum_{\mathrm{Ni}}^{\mathrm{Nn}} \text { LHRj x VDFj xDDxDLx365 } \\
& \text { dengan: } \\
& \mathrm{W}_{18}=\text { Traffic design pada lajur lalu } \\
& \text { lintas (ESAL) } \\
& \mathrm{LHRj}=\text { Lintasan harian rata-rata } \\
& \text { untuk jenis kendaraan } \\
& \text { tertentu (satuan kendaraan } \\
& \text { per hari). } \\
& \mathrm{VDFj}=\text { Faktor Ekivalen Beban } \\
& \text { (Vehicle Damage Factor) } \\
& \text { tiap jenis kendaraan } \\
& \text { DL = Faktor Distribusi Lajur. } \\
& \mathrm{DD}=\text { Faktor Distribusi Arah } \text {. } \\
& \mathrm{Ni}=\text { Lalu lintas tahun pertama } \\
& \text { dibuka jalan } \\
& \mathrm{Nn}=\text { Lalu lintas pada akhir tahun } \\
& \text { umur rencana }
\end{aligned}
$$

\subsection{Sisa Umur Rencana}

Sisa umur rencana (Remaining Life) adalah penyusutan dari umur rencana karena faktor beban kendaraan yang melintas. Masa layan jalan seharusnya akan habis sesuai dengan umur rencana yang sudah direncanakan. Tetapi sering terjadi, kendaraan yang melintas membawa beban yang melebihi ambang batas. Sehingga jalan lebih cepat mengalami kelelahan (fatiq). Karena itu, diperlukan perhitungan agar diketahui berapa sisa umur rencana/Remaining Life (RL), berdasarkan penurunan masa layan jalan tersebut. Nilai Remaining Life dapat dihitung dengan Persamaan 4, sebagai berikut.

$$
\mathrm{RL}=100\left[1-\left(\frac{\mathrm{Np}}{\mathrm{N}_{1.5}}\right)\right]
$$

dengan:

$$
\begin{aligned}
\mathrm{RL}= & \text { Remaining Life } \\
\mathrm{Np}= & \text { kumulatif ESAL per tahun. } \\
\mathrm{N}_{1.5}= & \text { kumulatif ESAL tahun } \\
& \text { terakhir umur rencana. }
\end{aligned}
$$

\subsection{Muatan Berlebih (Overload)}

Muatan berlebih merupakan suatu kondisi beban gandar kendaraan yang melampaui batas maksimum yang diizinkan. Kendaraan yang mengangkut muatan melebihi ketentuan batas beban yang sudah ditetapkan (berlebih) mengakibatkan daya rusak atau Vehivle Damage Faktor (VDF) kendaraan 
meningkat. Kerusakan yang terjadi lebih cepat. Sehingga dapat memperpendek masa pelayanan jalan. Sebab, pada perencanaan perkerasan jalan mengacu pada kondisi kendaraan dengan muatan standard atau normal (Ramdhani, 2016).

\section{METODE PENELITIAN}

\subsection{Lokasi Penelitian}

Studi dilakukan pada ruas Jalan Ahmad Yani, Narmada. Ruas jalan ini merupakan jalan kelas 1 yang berfungsi sebagai jalan arteri. Gambar 3 menunjukkan lokasi ruas jalan dimaksud.

Gambar 4, menunjukkan potongan melintang Jalan Ahmad Yani pada lokasi studi. Ruas jalan ini mempunyai ruang manfaat jalan untuk badan jalan, bahu jalan dan saluran samping.

\subsection{Jenis Data dan Analisis Data}

Data jumlah dan muatan kendaraan Tahun 2019 didapatkan dari Kantor Unit Pelaksana Penimbangan Kendaraan Bermotor (UPPKB) Bertais di Narmada (Anonim, 2019a) dan data lalulintas harian rata-rata (LHR) tahun 2018 dan 2019 dari Kantor Balai Pelaksana Jalan Nasional (BPJN) IX Mataram (Anonim, 2019b).
Analisis dilakukan dengan langkahlangkah sebagai berikut:

1. Menghitung jumlah kendaraan yang overload berdasarkan data jumlah, serta muatan masingmasing golongan kendaraan.

2. Mencari persentase muatan berlebih masing-masing golongan dengan menggunakan Persamaan 5.

Persentase muatan berlebih $=$ $\frac{\text { Hasil Penimbangan-JBI }}{\mathrm{JBI}} \times 100 \% \ldots$

dimana:

$\mathrm{JBI}=$ Jumlah Beban Ijin.

3. Menghitung pembagian beban sumbu masing-masing golongan kendaraan.

4. Menghitung angka ekivalen atau Vehicle Damage Factor (VDF) tiap golongan kendaraan.

5. Menghitung peningkatan $V D F$ kendaraan tiap golongan. Dimana, Peningkatan $V D F=$ Komulatif VDF overload Komulatif VDF muatan normal.

6. Menghitung sisa umur rencana akibat beban overload 


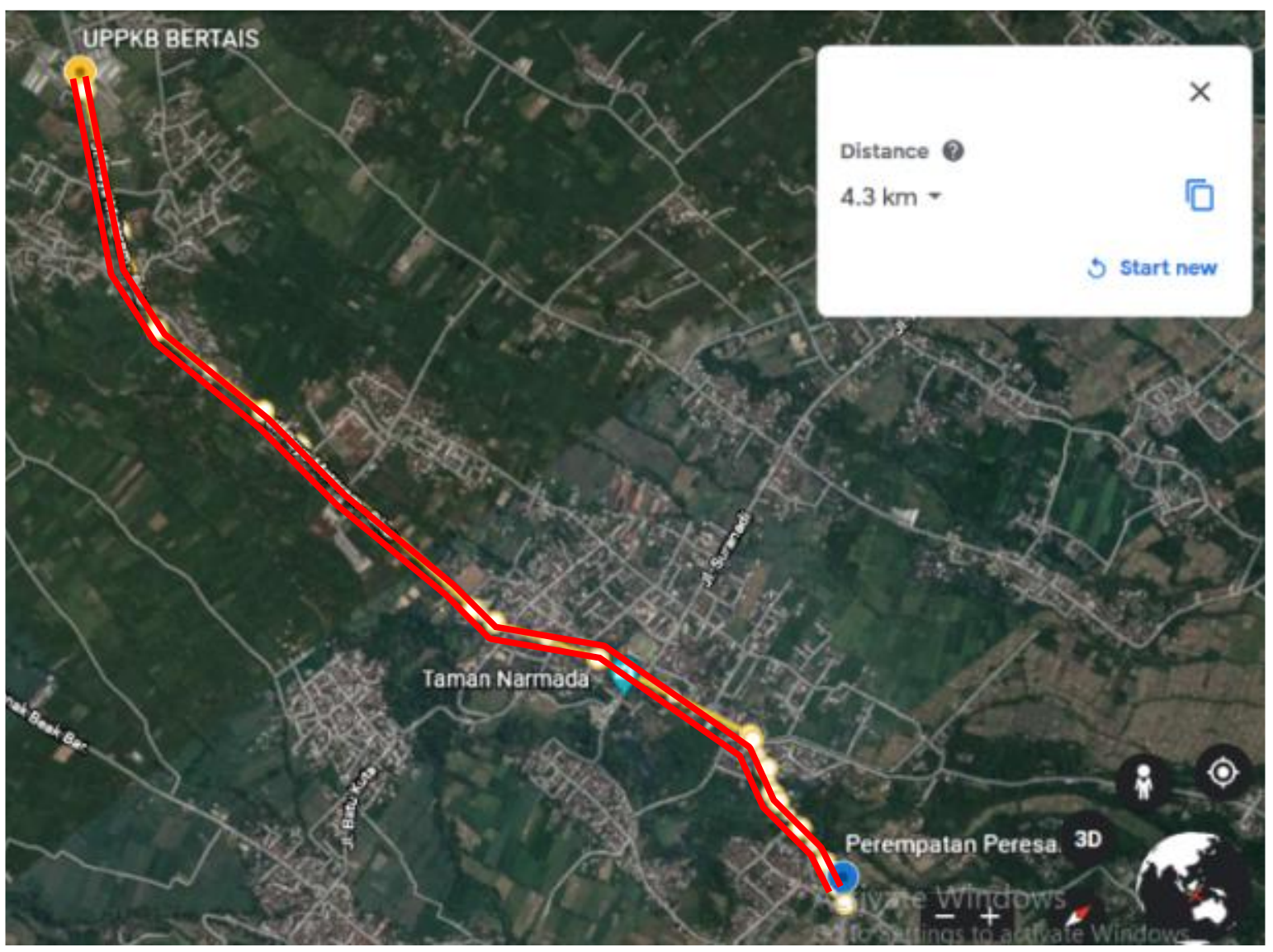

Gambar 3. Lokasi Penelitian

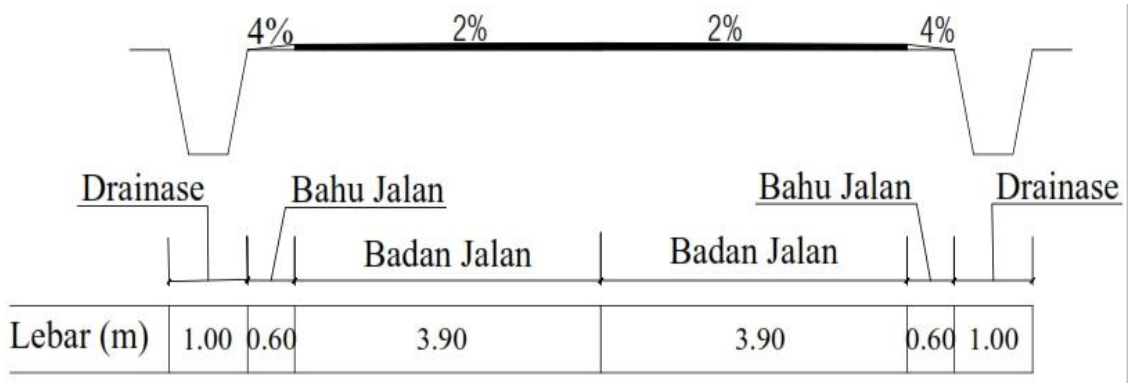

Gambar 4. Potongan Melintang Jalan Ahmad Yani.

\section{HASIL DAN PEMBAHASAN}

\subsection{Data Lalu Lintas Harian Rata-rata}

Data Lalu Lintas Harian Rata-rata (LHR) Tahun 2018 dan 2019 ditunjukkan pada Tabel 3.

\subsection{Data Muatan Kendaraan}

Tabel 4 menunjukkan data jumlah kendaraan yang masuk ke Jembatan Timbang Bertais. Termasuk kendaraan yang overload, yang didapatkan dari Kantor UPPKB Bertais. Kendaraan tersebut adalah untuk angkutan barang, termasuk dalam golongan 4, 6a, 6b dan 7a. 
Tabel 3. Data LHR Jalan Ahmad Yani

\begin{tabular}{lccc}
\hline \multicolumn{1}{c}{$\begin{array}{c}\text { Jenis } \\
\text { Kendaraan }\end{array}$} & Gol & $\begin{array}{c}\text { LHR } \\
\text { Tahun } \\
2018 \\
\text { (kend/hari) }\end{array}$ & $\begin{array}{c}\text { LHR } \\
\text { Tahun } \\
2019 \\
\text { (kend/hari) }\end{array}$ \\
\hline Pick up & 4 & 136 & 141 \\
$\begin{array}{l}\text { Truk 2 Sumbu } \\
\text { 4 Roda }\end{array}$ & $6 \mathrm{a}$ & 357 & 370 \\
$\begin{array}{l}\text { Truk 2 Sumbu } \\
\text { 6 Roda }\end{array}$ & $6 \mathrm{~b}$ & 277 & 289 \\
Truk 3 Sumbu & $7 \mathrm{a}$ & 38 & 39 \\
Jumlah & & 1837 & 1903 \\
\hline
\end{tabular}

Sumber: Anonim, $2019 b$

Tabel 4. Jumlah dan Jenis Kendaraan Masuk Jembatan Timbang

\begin{tabular}{|c|c|c|c|}
\hline $\begin{array}{c}\text { Jenis } \\
\text { Kendaraan } \\
(*)\end{array}$ & $\begin{array}{l}\text { Gol. } \\
\text { Kend. } \\
(*)\end{array}$ & $\begin{array}{c}\text { Jml. Kend. } \\
\text { (kend/hari) } \\
(* *)\end{array}$ & $\begin{array}{c}\text { Jml. Kend. } \\
\text { Overloadl } \\
\text { hari } \\
(* *)\end{array}$ \\
\hline Pick Up & 4 & 30 & 22 \\
\hline $\begin{array}{l}\text { Truk } 2 \text { As } \\
\text { Roda } 4\end{array}$ & $6 a$ & 73 & 56 \\
\hline $\begin{array}{l}\text { Ttruk } 2 \text { As } \\
\text { Roda } 6\end{array}$ & $6 b$ & 33 & 30 \\
\hline Truk 3 As & $7 a$ & 3 & 2 \\
\hline
\end{tabular}

\subsection{Analisa Beban Sumbu Kendaraan}

Beban kendaraan didistribusikan ke masing-masing sumbu berdasarkan proporsinya. Beban sumbu dilanjutkan ke permukaan jalan melalui roda. Jalan menerima perulangan beban selama masa pelayanan jalan. Kendaraan yang melewati Jumlah Beban Ijin (JBI), mengakibatkan penurunan masa layanan. Jalan Ahmad Yani, Kecamatan Narmada merupakan jalan kelas I (Anonim, 2019b).
Pada Tabel 5 menyajikan jenis, golongan, konfigurasi sumbu, JBI dan distribusi beban sembu kendaaraan yang melintas pada ruas Jalan Ahmad Yani, Kecamatan Narmada.

\section{Tabel 5. Beban Sumbu Kendaraan}

\begin{tabular}{|c|c|c|c|c|c|}
\hline No & $\begin{array}{c}\text { Jenis } \\
\text { Ken- } \\
\text { daraan } \\
(*) \\
\end{array}$ & $\begin{array}{c}\text { Gol. } \\
(*)\end{array}$ & $\begin{array}{c}\text { Konfigu- } \\
\text { rasi Sumbu } \\
\text { Kendaraan } \\
(* *)\end{array}$ & $\begin{array}{c}\text { JBI } \\
\text { (Ton) } \\
(* *)\end{array}$ & $\begin{array}{c}\text { Distri- } \\
\text { busi } \\
\text { beban } \\
(* *) \\
\end{array}$ \\
\hline 1 & Pick Up & 4 & 1.1 & 2.0 & \\
\hline 2 & $\begin{array}{l}\text { Truk } 2 \\
\text { As } \\
\text { Roda } 4\end{array}$ & $6 a$ & 1.2 & 8.3 & \\
\hline 3 & $\begin{array}{l}\text { Truk } 2 \\
\text { As } \\
\text { Roda } 6\end{array}$ & $6 b$ & 1.2 & 16.0 & \\
\hline 4 & $\begin{array}{l}\text { Truk } 3 \\
\text { As }\end{array}$ & $7 \mathrm{a}$ & 1.22 & 25.0 & \\
\hline
\end{tabular}

Sumber: (*) Anonim, 2019a; (**) Nurkholis, 2018

Pada Tabel 5, juga dapat dilihat bahwa Jalan Ahmad Yani dilewati oleh 4 jenis kendaraan dengan golongan yang berbeda. Namun, pada beberapa kendaraan mempunyai konfigurasi sumbu yang sama. Beban (muatan) sumbu terberat yang diperbolehkan melewati Jalan Ahmad Yani, Kecamatan Narmada adalah 10 ton. Karena jalan ini memiliki klasifikasi Kelas Jalan I.

\subsection{Muatan Berlebih Aktual Rata-rata}

Prosentase muatan lebih aktual ratarata dihitung dengan Persamaan 5. Hasil perhitungan persentase muatan aktual berlebih rata-rata untuk masing-masing jenis kendaraan dapat dilihat pada Tabel 6 . 
Tabel 6. Persentase Muatan Berlebih RataRata Tiap Golongan

\begin{tabular}{ccc}
\hline No & Golongan Kendaraan & Persentase $(\%)$ \\
\hline 1 & 4 & 36.83 \\
2 & $6 \mathrm{a}$ & 55.88 \\
3 & $6 \mathrm{~b}$ & 77.07 \\
4 & $7 \mathrm{a}$ & 54.13 \\
\hline
\end{tabular}

Tabel 6 menunjukkan bahwa persentase terbesar muatan berlebih ratarata untuk tiap golongan kendaraan berdasarkan data pada UPPKB Bertais adalah kendaraan dengan golongan $6 \mathrm{~b}$ sebesar $77.07 \%$. Kemudian golongan 6a sebesar $55.88 \%$ serta golongan $7 \mathrm{a}$ dan 4 masing-masing sebesar $54.13 \%$ dan $36.83 \%$.

\subsection{Vehicle Damage Factor Kendaraan}

Vehivle Damage Faktor (VDF) atau angka ekivalen kendaraan dihitung untuk kendaraan dengan muatan standar dan muatan berlebih. Rekapitulasi hasil perhitungan VDF atau angka ekivalen kendaraan ditunjukkan pada pada Tabel 7 dan 8 .

Tabel 7. VDF Muatan Normal

\begin{tabular}{|c|c|c|c|c|c|}
\hline \multirow{2}{*}{$\begin{array}{c}\text { Jenis } \\
\text { Kendaraan }\end{array}$} & \multirow{2}{*}{ Gol } & \multirow{2}{*}{$\begin{array}{c}\text { Konfi } \\
\text { gurasi } \\
\text { Sumb } \\
\text { u }\end{array}$} & \multicolumn{2}{|c|}{ Beban Sumbu (ton) } & \multirow{2}{*}{ VDF } \\
\hline & & & Depan & Belakang & \\
\hline Pick up & 4 & 1.1 & 0.680 & 1.320 & 0.0007 \\
\hline $\begin{array}{l}\text { Truk } 2 \text { as } 4 \\
\text { Roda }\end{array}$ & $6 a$ & 1.2 & 2.822 & 5.478 & 0.2174 \\
\hline $\begin{array}{l}\text { Truk } 2 \text { as } 6 \\
\text { Roda }\end{array}$ & $6 b$ & 1.2 & 5.440 & 10.560 & 3.0023 \\
\hline Truk 3 as & $7 \mathrm{a}$ & 1.22 & 6.250 & 18.750 & 2.7416 \\
\hline
\end{tabular}

Tabel 8. VDF Muatan Berlebih Aktual

\begin{tabular}{|c|c|c|c|c|c|}
\hline \multirow{2}{*}{$\begin{array}{c}\text { Jenis } \\
\text { Kendaraan }\end{array}$} & \multirow{2}{*}{ Gol } & \multirow{2}{*}{$\begin{array}{l}\text { Konfi- } \\
\text { gurasi } \\
\text { Sumbu }\end{array}$} & \multicolumn{2}{|c|}{$\begin{array}{l}\text { Beban Sumbu } \\
\text { (ton) }\end{array}$} & \multirow{2}{*}{ VDF } \\
\hline & & & Depan & Belakang & \\
\hline Pick up & 4 & 1.1 & 0.93 & 1.806 & 0.0026 \\
\hline $\begin{array}{l}\text { Truk } 2 \text { as } 4 \\
\text { Roda }\end{array}$ & $6 a$ & 1.2 & 4.398 & 8.539 & 1.2835 \\
\hline $\begin{array}{l}\text { Truk } 2 \text { as } 6 \\
\text { Roda }\end{array}$ & $6 b$ & 1.2 & 9.120 & 17.707 & 23.7331 \\
\hline Truk 3 as & $7 \mathrm{a}$ & 1.22 & 9.630 & 28.890 & 15.4520 \\
\hline
\end{tabular}

\subsection{Peningkatan VDF Kumulatif akibat Muatan Berlebih Aktual}

VDF komulatif akibat muatan normal adalah komulatif dari jumlah kendaraan/ tahun dikalikan dengan VDF normal. Hasil perhitungan selengkapnya pada Tabel 9.

Tabel 9. VDF Kumulatif akibat Muatan Normal

\begin{tabular}{cccc}
\hline Gol & $\begin{array}{c}\text { Jumlah } \\
\text { Kendaraan/ } \\
\text { Tahun }\end{array}$ & $\begin{array}{c}\text { VDF } \\
\text { Normal }\end{array}$ & $\begin{array}{c}\text { VDF } \\
\text { Komulatif } \\
\text { Normal }\end{array}$ \\
\hline 4 & 51465 & 0.0007 & 36.0255 \\
$6 \mathrm{a}$ & 135050 & 0.2174 & 29359.8700 \\
$6 \mathrm{~b}$ & 105485 & 3.0023 & 316697.6155 \\
$7 \mathrm{a}$ & 14235 & 2.7416 & 39026.6760 \\
& & Total & 385120.1870 \\
\hline
\end{tabular}

Sedangkan VDF komulatif akibat muatan berlebih aktual adalah komulatif dari jumlah kendaraan/ tahun dikurangi jumlah kendaraan overload/ tahun dikalikan dengan VDF normal, kemudian ditambah jumlah kendaraan overloadl tahun dikalikan VDF overload. Misal, untuk kendaraan Golongan 4, maka: VDF komulatif overload $=(51465-8030) \mathrm{x}$ $0.0007+8030 \times 0.0026=51.2825$. Hasil selengkapnya ditunjukkan pada Tabel 10. 
Tabel 10. VDF Kumulatif akibat Muatan Berlebih Aktual

\begin{tabular}{cccc}
\hline Gol & $\begin{array}{c}\text { Jumlah } \\
\text { Kendaraan/ } \\
\text { Tahun }\end{array}$ & $\begin{array}{c}\text { VDF } \\
\text { Overload }\end{array}$ & $\begin{array}{c}\text { VDF } \\
\text { Komulatif } \\
\text { Overload }\end{array}$ \\
\hline 4 & 8030 & 0.0026 & 51.2825 \\
$6 \mathrm{a}$ & 20440 & 1.2835 & 51150.9540 \\
$6 \mathrm{~b}$ & 10950 & 23.7331 & 543699.8755 \\
$7 \mathrm{a}$ & 730 & 15.452 & 48305.2680 \\
& & Total & 643207.3800 \\
\hline
\end{tabular}

Berdasarkan Tabel 9 dan Tabel 10, dapat dilihat bahwa:

1. Total VDF Kumulatif akibat Muatan Berlebih Aktual adalah 643207.3800 .

2. Total VDF Kumulatif akibat Muatan Normal adalah 385120.1870 .

Maka, peningkatan VDF kumulatif akibat muatan berlebih aktual, adalah: $643207.3800-385120.1870=$ 258087.1930 .

Peningkatan dalam persentase adalah:

$$
\begin{aligned}
& \frac{\text { Peningkatan VDF }}{\text { Total VDF kumulatif normal }} \times 100 \% \\
& =\frac{258087.1930}{385120.1870} \times 100 \%=67.01 \%
\end{aligned}
$$

\subsection{Penurunan Umur Rencana}

Penurunan umur rencana (masa layanan), didapatkan dengan melakukan analisis terhadap kondisi kendaraan dengan muatan normal (standar) dan muatan berlebih. Tabel 11 menunjukkan prosentase remaining life (RL) untuk kondisi muatan normal dari tahun ke 1 sampai tahun ke 10.
Tabel 11. Umur Rencana pada Kondisi Muatan Normal

\begin{tabular}{ccccc}
\hline No & $\begin{array}{c}\text { Tahun } \\
\text { ke- }\end{array}$ & $\begin{array}{c}\text { Np } \\
(E S A L)\end{array}$ & N1.5(ESAL) & RL $(\%)$ \\
\hline 1 & 1 & 153993.2 & 1806555 & 91.5 \\
2 & 2 & 313376.2 & 1806555 & 82.7 \\
3 & 3 & 478337.6 & 1806555 & 73.5 \\
4 & 4 & 649072.6 & 1806555 & 64.1 \\
5 & 5 & 825783.4 & 1806555 & 54.3 \\
6 & 6 & 1008679.0 & 1806555 & 44.2 \\
7 & 7 & 1197976.0 & 1806555 & 33.7 \\
8 & 8 & 1393898.4 & 1806555 & 22.8 \\
9 & 9 & 1596678.1 & 1806555 & 11.6 \\
10 & 10 & 1806555.0 & 1806555 & 0 \\
\hline
\end{tabular}

Gambar 5, menunjukkan grafik persentase penurunan umur rencana pada muatan normal berdasarkan hasil perhitungan pada Tabel 11. Grafik ini menunjukkan bahwa akhir masa layanan berakhir pada tahun ke 10 .

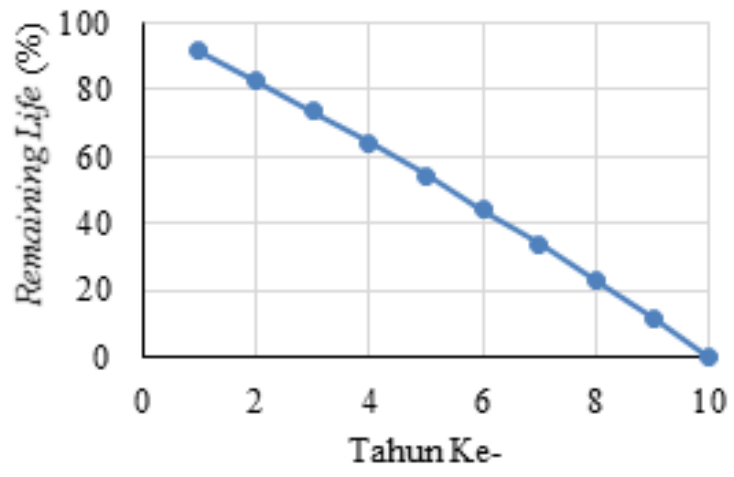

Gambar 5. Penurunan Umur Rencana pada Muatan Normal

Umur rencana akibat muatan berlebih actual, dihitung dengan cara yang sama sepertipada perhitungan umur rencana untuk muatan normal. Perbedaannya hanya pada penggunaan VDF kumulatif. Pada perhitungan dengan kondisi muatan berlebih digunakan VDF kumulatif akibat muatan berlebih. Hasil perhitungan selengkapnya ditunjukkan pada Tabel 12. 
Tabel 12. Umur Rencana pada Kondisi Muatan Berlebih Aktual

\begin{tabular}{ccccc}
\hline No & $\begin{array}{c}\text { Tahun } \\
\text { ke- }\end{array}$ & $\begin{array}{c}\text { Np } \\
(E S A L)\end{array}$ & N1.5(ESAL) & RL $(\%)$ \\
\hline 1 & 1 & 234628.3 & 1806555 & 87.0 \\
2 & 2 & 477468.5 & 1806555 & 73.6 \\
3 & 3 & 728808.1 & 1806555 & 59.7 \\
4 & 4 & 988944.7 & 1806555 & 45.3 \\
5 & 5 & 1258185.9 & 1806555 & 30.4 \\
6 & 6 & 1536850.7 & 1806555 & 14.9 \\
7 & 7 & 1825268.8 & 1806555 & -1.1 \\
8 & 8 & 2123781.4 & 1806555 & -17.6 \\
9 & 9 & 2432742.0 & 1806555 & -34.7 \\
10 & 10 & 2752516.2 & 1806555 & -52.4 \\
\hline
\end{tabular}

Gambar 6, adalah grafik persentase penurunan umur rencana atau masa layanan jalan, akibat muatan berlebih berdasarkan hasil perhitungan pada Tabel 12.

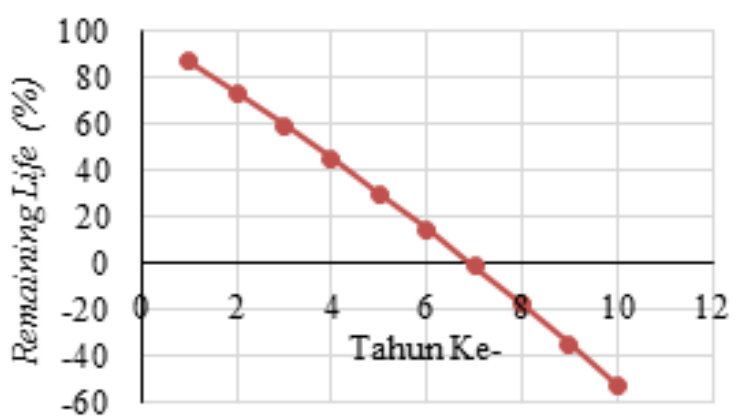

Gambar 6. Penurunan Umur Rencana pada Muatan Berlebih

Gambar 6 menunjukkan bahwa sisa umur rencana (remaining life) $0 \%$, terjadi antara tahun ke-6 dan tahun ke-7. Pada tahun ke-6 persentase umur rencana $14.9 \%$ dan pada tahun ke-7 persentase umur rencana $-1.1 \%$. Maka secara analitis sisa umur rencana dapat dihitung dengan cara interpolasi, sebagai berikut:

$$
\begin{aligned}
& \frac{14.9 \%+1.1 \%}{7-6}=\frac{14.9 \%}{x} \\
& x=\frac{14.92 \%}{14.9 \%+1.1 \%} \cdot(7-6) \\
& x=0.935
\end{aligned}
$$

Nilai umur rencana $=6+0.935=$ 6.935 tahun. Sehingga penurunan umur rencana akibat muatan berlebih yang terjadi adalah $10-6.935=3.1$ tahun $=30.65 \%$.

\subsection{Perbandingan Penurunan Masa Layanan \\ Gambar 7 menunjukkan} perbandingan persentase penurunan umur rencana pada kondisi normal dengan kondisi akibat muatan berlebih aktual.

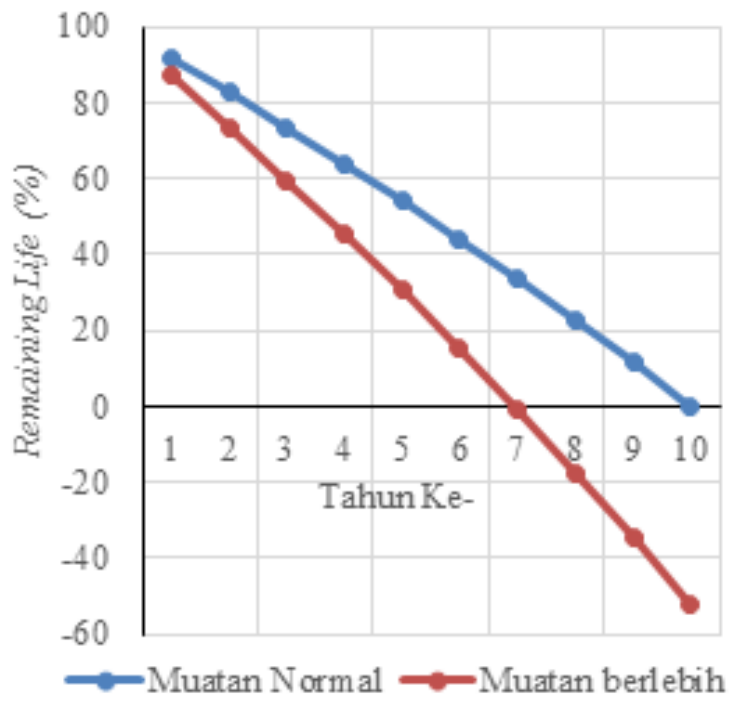

Gambar 7. Perbandingan Penurunan Umur Rencana pada Muatan Normal dan Muatan Berlebih

Gambar 7 mengilustrasikan bahwa, dengan beban berlebih jalan mengalami kerusakan pada mendekati tahun ke 7 (6.9 tahun). Artinya, umur layanan telah habis 3.1 tahun lebih awal daripada jika kendaraan yang melintas dengan muatan normal. 


\section{SIMPULAN DAN SARAN}

\subsection{Simpulan}

Kesimpulan dari studi ini adalah sebagai berikut:

1. Berdasarkan muatan normal, diperoleh angka ekivalen kendaraan sebesar 2.7416 (golongan 7a), 3.0023 (golongan 6b), 0.2174 (golongan 6a) dan 0.0007 (golongan 4).

2. Berdasarkan muatan lebih aktual, diperoleh angka ekivalen kendaraan sebesar 23.7331 (golongan 6b), 15.452 (golongan 7a), 1.2835 (golongan 6a) 0.0026 (golongan 4).

3. Terjadi peningkatan nilai $V D F$ kumulatif, kendaraan angkutan barang sebesar $67.01 \%$, akibat muatan berlebih aktual.

4. Dampak beban berlebih aktual, menyebabkan penurunan umur rencana, sebesar $30.65 \%$ atau selama 3.1 tahun.

\subsection{Saran}

Penelitian ini adalah merupakan studi dengan data sekunder untuk memperkirakan penurunan umur rencana. Penelitian selanjutnya diperlukan untuk memperkuat hasil analisis, terutama dari sisi kondisi jalan sampai dengan saat ini.
Sehingga dapat digunakan sebagai verifikasi terhadap hasil dari studi ini.

\section{DAFTAR PUSTAKA}

Abdillah, S. H., Paransa, M. J., Jansen, F., \& Manoppo, M. R. E. (2013). Studi Pengaruh Pengambilan Angka Ekivalen Beban Kendaraan pada Perhitungan Tebal Perkerasan Fleksibel di Jalan Manado-Bitung. Jurnal Sipil Statik, 1(7), 505-514.

Anonim. (1987). Petunjuk Perencanaan Tebal Perkerasan Lentur Jalan dengan Metode Analisa Komponen. Jakarta: Direktorat Jenderal Bina Marga, Departemen Pekerjaan Umum.

Anonim. (1993). Guide for Design of Pavement Structures. Washington DC: AASHTO.

Anonim. (2004). A Guide to the Visual Assesment of Pavement Condition. Australia: NAASRA.

Anonim. (2005). Perencanaan Perkerasan Jalan. Jakarta: Direktorat Jenderal Bina Marga, Departemen Pekerjaan Umum.

Anonim. (2009). Undang-Undang Republik Indonesia No.22 Tentang Lalu Lintas dan Angkutan Jalan. Jakarta: Pemerintah Republik Indonesia.

Anonim. (2019a). Data Kendaraan Masuk Jembatan Timbang. Unit Pelaksana Penimbangan Kendaraan Bermotor Bertais.

Anonim. (2019b). Data LHR Jalan Ahmad Yani. Balai Pelaksanaan Jalan Nasional IX Mataram.

Apriyadi, F., \& Fauziah, M. (2018). Pengaruh Beban Berlebih Kendaraan Berat Terhadap Umur Rencana Perkerasan Kaku Pada Jalan 
Diponegoro, Cilacap. Prosiding Seminar Nasional Teknik Sipil 2018. Surakarta: Fakultas Teknik Universitas Muhammadiyah.

Handayasari, I., \& Cahyani, R. D. (2016). Pengaruh Beban Berlebih Terhadap Umur Rencana Perkerasan Jalan (Studi Kasus Ruas Jalan Soekarno Hatta Palembang). KILAT, 5(1), 2532.

Nurkholis, H. (2018). Analsis Beban Berlebih Kendaraan Pada Perkerasan Lentur Terhadap Penurunan Umur Rencana Perkerasan Jalan. Tugas Akhir. Universitas Islam Indonesia Yogyakarta.

Pardosi, R. (2010). Studi Pengaruh Beban Berlebih (Overload) terhadap Pengurangan Umur Rencana Perkerasan Jalan. Universitas Sumatera Utara.

Ramdhani, F. (2016). Analisis Dampak Beban Overload Kendaraan pada Struktur Flexible Pavement terhadap Umur Rencana Perkerasan pada Pembangunan Jalur Baru Jalan Soekarno-Hatta (Sta $12+000 \quad$ s/d 13+000) Kota Dumai. The 19th International Symposium of FSTPT. Yogyakarta: Islamic University of Indonesia.

Safitra, P. A., Sendow, T. K., \& Pandey, S. V. (2019). Analisa Pengaruh Beban Berlebih terhadap Umur Rencana Jalan (Studi Kasus: Ruas Jalan Manado - Bitung). Jurnal Sipil Statik, 7(3), 319-328.

Sentosa, L., \& Roza, A. A. (2012). Analisis Dampak Beban Overloading Kendaraan pada Struktur Rigid Pavement Terhadap Umur Rencana Perkerasan (Studi Kasus Ruas Jalan Simp Lago-Sorek Km 77 S/D 78). Jurnal Teknik Sipil, Jurnal Teoretis
Dan Terapan Bidang Rekayasa Sipil, 19(2), 161-168.

Sukirman, S. (2010). Perkerasan Lentur Jalan Raya. Bandung: Nova.

Yun. (2019). Jembatan Timbang Poto Tano Butuh Perbaikan. Redaksi Lombok Post. 